\title{
Teach How to Listen: The Effect of Listening Strategy Instruction on Documentary Video Comprehension
}

\author{
Fatemeh Hosseini \\ Department of English Language Teaching, Imam Khomeini International University, Qazvin, Iran \\ E-mail address: Hosseini.fatemeh27@yahoo.com
}

\begin{abstract}
Developments in broadcast and multimedia technology have generated a readily available and vast supply of videos for use in second and foreign language learning contexts. However, without pedagogical direction learners are unlikely to be able to deal with the complexities of this authentic listening resource, and strategy instruction may be one route to augmenting comprehension (Cross, J, 2009). The essence of this experimental study was to investigate the impact of teaching listening strategy on comprehension of documentary videos. For the purpose of this study, 54 advanced EFL students, 27 in experimental group and 27 in control group, participated in this study procedure. In 10-week-period, the experimental group went through a well-scheduled instruction in listening strategy. On the other hand, the control group wasn't received any instruction in listening strategy. The finding of this study has revealed that teaching listening comprehension strategies has significant influence on comprehension of authentic documentary videos.
\end{abstract}

Keywords: listening strategy; strategy instruction; listening comprehension; documentary video

\section{INTRODUCTION}

In the past 10 years, advances in satellite, digital video and broadband technology have brought about a notable rise in the number of dedicated documentary channels and documentary video company producer. These documentary videos provide a wealth of authentic videos that are a dynamic cultural, linguistic and educational resource ripe for exploitation within second and foreign language classrooms, self-access centers and home study environments to develop learners 'real world' listening ability. For many learners of English the ability to understand documentary videos is perhaps the 'holy grail' of second language listening comprehension. However, the particular characteristics of documentary videos present a number challenges to achieving comprehension (Cross, J, 2009):

1) unfamiliar patterns of discourse, 2 vocabulary, speech rates, prosody and syntactic structures;

2) a high density of factual content;

3) disorienting visual cuts; and

4) discrepancies between aural and visual information 
Furthermore, problems may arise due to insufficient background knowledge, familiar vocabulary that becomes unfamiliar in connected speech or was not expected in the given context, no opportunity to negotiate meaning, and unfamiliar contexts and cultural norms (Meinhof, 1998).

Typically, learners are unaware of how to set about dealing with the inherent complexities of documentary videos, often perceiving visuals as a distraction and disregarding them in favor of striving to comprehend and recall every single detail of the audio. Learners relying on such an approach may have inappropriate perceptions of what reflects successful comprehension of documentary videos, and when their unrealistic expectations of detailed understanding are not met it can result in frustration and de-motivation. While pedagogical direction can help to alleviate these concerns, there can be a propensity for teachers to be unaware of the particular characteristics of documentary videos and exploit them as they would textbook listening material, normally setting tasks such as gap fill completion which focus on listening for specific details and which learners carry out as the documentary videotext is played. The outcome of this practice is that task utilization does little to promote 'real world' listening skills germane to comprehending documentary videos; the constituents of the audio are given precedence and possible contextual support provided by accompanying visuals is neglected, thereby inhibiting the transmission of the overall message documentary videos are crafted to convey; and the misconception among learners that successful listening is reflected in word-for-word comprehension of documentary videos is inadvertently reinforced, further encouraging an overdependence on bottom-up processing.

Given the nature and complexity of documentary videos, learners might be better served by shifting the focus of instruction towards initially developing their ability to exploit both audio and visual channels in conjunction with encouraging a greater preference initially for utilizing top-down processes (e.g. exploiting contextual knowledge) to attempt to reconstruct meaning. This may help to ease the burden on learners' limited working-memory capacity, enable learners to achieve a measure of understanding that reflects success in listening to documentary videos at their level of ability, cultivate 'real world' listening skills and moderate possible affective concerns. Thus, meaning-based comprehension of documentary videos can form the 'conceptual framework' (Vandergrift, 2003a) upon which learners may subsequently build towards more detailed understanding as they are also helped to develop bottom-up processes (e.g. phoneme and word recognition) and linguistic ability.

The implementation of listening strategy instruction may be a key component in helping learners give preference to top-down processes for extracting meaning when attempting to comprehend documentary videos, and this classroom-based study investigates the explicit teaching of strategies to Iranian advanced level EFL learners and its impact on their listening comprehension ability.

\section{1. Literature Review}

There has been abundant research into strategies for language learning and language use, with findings suggesting strategy instruction helps promote the effective use of strategies (Chamot, 2005), and that a generally positive correlation exists between strategy use and second language (L2) proficiency (Oxford et al., 2004). The theoretical framework which underpins learning strategies is rooted in cognitive psychology and information-processing theory (Anderson, 1980). However, Macaro (2006) suggests a number of concerns regarding learning strategy research that weakens its theoretical foundation, such as the vagueness of definitions, a lack of agreement on the connection of strategies to processes and skills, and uncertainty regarding strategy transferability across tasks, situations and contexts. In light of these 
concerns, Macaro $(2004 ; 2006)$ offers a revised, contemporary, cognitive theoretical framework in which the essential features of strategies include:

1) Strategies are conscious mental activity only occurring in working-memory.

2) Strategies are orchestrated in clusters (by effective learners) and these clusters are both situation- and task-specific and transferable.

3) Strategies can become automatic (though as some other construct in long-term memory), freeing up working-memory space, but may again come under conscious control in working-memory in response to a change in learning goal, desired outcome, and/or situation.

4) Strategies may be inhibited by working-memory limitations or when a learner is below a certain linguistic threshold.

5) Interdependent top-down and bottom-up processes consist of clusters of strategies in a dynamic in working-memory, and 'it is in the application of these strategies ... that (explicit) L2 processes take place' (Macaro, 2006, p. 330); and

6) The repeated activation (in working-memory) and subsequent automatic (in long-term memory) of top-down and bottom-up processes bring about skill development.

With respect to listening strategies, O'Malley and Chamot's (1990) taxonomy of cognitive, meta-cognitive and social-affective strategies and Vandergrift's $(1996 ; 1997)$ refined version have to date gained widest acceptance among researchers. Grounded in information-processing theory, these taxonomies have facilitated clarification and categorization of the manner in which listening strategy use is orchestrated. Numerous studies have examined more-proficient and less-proficient listeners, and findings indicate that more-proficient listeners use a wider variety of strategies with greater flexibility, frequency, sophistication, and appropriateness to meet task demands (e.g. Chien and Wei, 1998; Goh, 2002; Smidt and Hegelheimer, 2004), and employ superior configurations of strategies compared to less-proficient listeners (e.g. Vandergrift, 1997; 1998; 2003a).

The premise that promoting the use and development of listening strategies through explicit instruction is conducive to helping learners become more efficient, effective and autonomous listeners is evident in recent literature on L2 listening pedagogy (e.g. Flowerdew and Miller, 2005; Lynch and Mendelsohn, 2002; Rost, 2002; Vandergrift, 2004). Nevertheless, there are a number of concerns related to listening strategy instruction. For example, Ridgway (2000) has argued that learners do not have the cognitive capacity to consciously activate taught strategies and listen simultaneously, and isolating individual listening strategies for explicit instruction and determining if they are being utilized by listeners is unrealistic. In addition, Field $(1998 ; 2000)$ has pointed out that proclivity toward listening strategy instruction and strategy use depends on an individual's temperament; targeting individual listening strategies for instruction may promote the use of those strategies but may not necessarily lead to improved listening performance; and he questions whether, following instruction, strategies can be utilized in combination and appropriately by listeners. More recently, Chen (2005) found learners reported a range of barriers encountered during a program of instruction classified as affective, habitudinal, information-processing, English proficiency, strategic, belief and material, which may inhibit the learning of listening strategies.

Despite the pedagogical and theoretical arguments, there has been little associated empirical research conducted, and the few studies thus far have not produced tangible and consistent findings to convincingly support or refute the efficacy of listening strategy instruction. For example, studies reported improvements in the use of some of the listening strategies taught but not others (e.g. McGruddy, 1995; Rost and Ross, 1991), listening 
comprehension post-test results have been mixed (e.g. Ozeki, 2000; Paulauskas, 1994; Thompson and Rubin, 1996), or methodological concerns limit the weight of positive findings (e.g. Carrier, 2003). With particular relevance to listening strategy instruction for documentary videos, Seo (2000) also reported inconsistent results. In her study, Seo initially used the multiple-choice Japanese Language Proficiency Test to determine the baseline listening ability of 10 Australian tertiary level Japanese as a foreign language learners. She then selected three cognitive strategies (identify key terms, elaborate and inference) identified in verbal protocols in the first phase of the study as pertinent to facilitating comprehension of Japanese documentary, and these were taught to a randomly assigned intervention group of five learners. The instruction program of 1 hour a week for 5 weeks consisted of three 1-hour strategy instruction sessions involving teacher modeling of strategies through concurrent verbal reporting and two 1-hour practice sessions in which participants verbalized strategy use. This was later followed by a 1-hour review session.

Post instruction, the intervention group (IG) and a non-intervention group (NIG) were shown a total of seven documentary videos at an interval of one video-text every two weeks and, following each broadcast, completed a multiple choice, true/false and key-word identification comprehension test. Despite noticeable IG improvements in performance compared to the NIG, the NIG also recorded gains and outperformed the IG in five of the seven post-tests. Hassan et al. (2005) point out that Seo's findings should be viewed with caution as the sample size was small, there were possible test familiarity effects across the study, and the results from the seven videotext tests were compared with results from the baseline audio-only pre-test.

While the results of Seo's study lack weight (Hassan et al., 2005) in terms of supporting the potency of listening strategy instruction with respect to documentary videos, such a small body of existing research on classroom-based investigations into the development and implementation of strategy instruction to promote listening comprehension in general and of this genre in particular underlines that there is clearly a need for further research to inform pedagogical practice. Thus, the research question for this study was: Does listening strategy instruction improve learners' ability to comprehend documentary videos?

\section{METHOD}

\section{1. Research Question}

Does listening comprehension strategy instruction improve documentary video comprehension?

\section{2. Research Hypothesis}

For the purpose of testing this investigation a Null Hypothesis was run:

Listening comprehension strategy instruction has no effect on improving documentary video comprehension.

\section{3. Participants}

A total of 54 Iranian advanced EFL learners of Goya institute in Marvdasht, Shiraz participated in this study. The participants were all female and had age range of 18 to 20. In summer 2013 the institute provided a free credit course of listening comprehension program (LCP). The purpose of the program was to do Listening Comprehension Strategy Instruction 
(LCSI). After the institute did advertise the LCP program 54 volunteer students all in advanced level of language proficiency based on the institute report registered in it. These 54 students were studying English for at least three years in Goya institute and their proficiency level was clear for the institute, yet for the confirmation of this fact a proficiency test was conducted. The 54 participants then divided into two groups; an experimental group $(\mathrm{n}=27)$ and a control group $(n=27)$. Prior to the start of the program and in the registration day students were informed of programs objectives and goals. For the instruction section, two experienced teachers were chosen to work on both classes. The program duration was 10 weeks each week two sessions. For the experimental groups each session took 120 minutes; in which 30 minutes devoted to instruction of listening comprehension strategy and some teacher and students exercises and 90 minutes was devoted to watch documentary videos and to do the listening comprehension tasks. On the other hand, in the control group each session took 90 minutes and all of the time was devoted to watch documentary videos and to do related exercises without any strategy instruction. Both experimental group and control group attended in a wellequipped computer laboratory included 30computers and headsets for listening comprehension.

\section{4. Instruments}

BBC documentary videos in different topics: Planet earth, Human History, New World, and New Technology were selected as the video/ audio materials for students to listen and to comprehend. The difficulty levels of the selected documentaries were ranked by BBC rater as ADVANCED and suitable for Advanced EFL learners. Ten documentaries were chosen to be worked on in 20sessions in the both classes, so each two sessions, students worked on one documentary. For each of this documentaries 20 listening comprehension questions were provided that students were responsible to work on it each session. As it was said earlier the experimental group was under the instruction of listening comprehension strategy. To fulfill this, the teacher prepared a pamphlet on Listening Comprehension Strategy based on the new published book of How to Teach Listening by JJ Wilson and taught it in the 30 minutes before the start of watching the documentary. Finally, SPSS 16 was used which promoted the accuracy of the results.

\section{5. Procedure}

54 Iranian advanced EFL students of Goya institute of Marvdasht, Shiraz enrolled in a free credit in listening comprehension program (LCP) due to their interest and without any obligation. They were divided into two classes each included 27 students. In the class A students went through listening comprehension strategy instruction. In the beginning of each session the instructor taught one listening comprehension strategy for 20 minutes and then for another 10 minutes the instructor and students did a real exercise in accordance with that strategy. After the instruction students started to watch the documentary video for 90 minutes and tried to do the strategy on that documentary. After watching the documentary students were required to answer to 20 listening comprehension questions. The One Day One Strategy Method was the run in Class A. During the 20 sessions ten listening comprehension strategies were covered. The following are the covered listening strategies based on How to Teach Listening by JJ Wilson.

- Use world knowledge to predict what will be said

- Use linguistic knowledge to predict what will be said

- Monitor performance while listening

- Pick out only salient points, listening selectively and ignoring irrelevant details 
- Take note, writing down relevant details in shorthand

- Listen for key words for topic identification

- Check with other listener

- Ask for clarification

- Reconstructing orally or in writing

- Listen for transition points

In the class B, student weren't received any listening comprehension strategies and all the class time was devoted to work on listening comprehension of documentary videos in a Watch and Comprehend Method. Each session the teacher of this class played a documentary video from the beginning of the class time and wanted the students to watch, to listen, and to discuss it with their friends till the end of it and then they were required to answer the 20 listening comprehension of that documentary video.

Each two weeks, students took a listening comprehension test as the same Class A did. In the last session the final test was conducted and the data pt in the SPSS to draw the final conclusion.

\section{RESULTS}

This section presents the results of the surveys administered prior to and at the end of the course. At the end of the course and after the data gathered the following result achieved. First table 1 is the illustration of descriptive statistics for both experimental and control groups labeled as Class A and Class B during the five periodical tests.

By analyzing the means score during the five periodical tests it comes to emerge that class A has improved its ability in listening comprehension of documentary videos. For the first test, students know little about listening comprehension strategies so the first mean score is not so high and it is about 59.85, yet it is 4.71 more than the same test in class B who did it without listening comprehension strategy. Little by little and with the increasing in listening comprehension strategy instructions the means score in class A increased in test two 63.03, test three 66.74, test four 73.07, and test five 77.51 that shows the effect of instructing listening comprehension strategies. On the other hand, the means score in class B show some Ups and Downs in test two, and test five that show class B didn't have the stability we saw in the class A means score.

The comparison between the total means score of class A and class B should be considered to address the research question. The total means score for class $\mathrm{A}$ is 68.04 and the amount of means score for class B is 58.08, so the amount of means score for class A is 9.96 more than class B that confirm the YES answer to it. So instructing listening comprehension strategy improves Iranian advanced EFL students listening comprehension of documentary videos. For the addressing of the research hypothesis the Tests of Between-Subjects Effects was run. Table two indicates the results. 
Table 1. Descriptive Statistics of Class A and Class B.

\begin{tabular}{lllll}
\hline & Test & Mean & Std. Deviation & N \\
\hline Class A & Test One & 59.8519 & 11.68728 & 27 \\
& Test Two & 63.0370 & 10.79345 & 27 \\
& Test Three & 66.7407 & 11.10991 & 27 \\
& Test Four & 73.0741 & 9.34355 & 27 \\
\hline Total & Test Five & 77.5185 & 8.99303 & 27 \\
\hline Class B & Test One & 68.04 & 12.15 & 27 \\
& Test Two & 55.1481 & 9.34264 & 27 \\
& Test Three & 53.4444 & 8.35894 & 27 \\
& Test Four & 59.1111 & 8.62614 & 27 \\
\hline Total & Test Five & 61.5556 & 9.58096 & 27 \\
\hline
\end{tabular}

Table 2. Tests of Between-Subjects Effects.

\begin{tabular}{|c|c|c|c|c|c|c|c|}
\hline Source & $\begin{array}{c}\text { Dependent } \\
\text { Variable }\end{array}$ & $\begin{array}{c}\text { Type III Sum of } \\
\text { Squares }\end{array}$ & $\mathrm{df}$ & Mean Square & $\mathrm{F}$ & Sig. & Partial Eta Squared \\
\hline \multirow[t]{2}{*}{ Test } & Class A & 5641.585 & 4 & 1410.396 & 12.947 & .000 & .285 \\
\hline & Class B & 1427.452 & 4 & 365.863 & 4.369 & .062 & .118 \\
\hline
\end{tabular}

The $p=.000$ in class $\mathrm{A}$ that reject the Null hypothesis of this research so Listening comprehension strategy instruction has effect on improving documentary video comprehension.

For more tangible illustration of changing and shifting in the means score of the two classes, two figures were provided by SPSS. Fig. 1 is showing the means score of class A, the experimental group, in which students went through listening comprehension strategy instruction.

As it is illustrated in the Fig. 1 students means score that are symbols for their listening comprehension abilities of documentary videos are increasing time to time and test to test. This fact is the confirmation of the significant effect of listening comprehension strategy instruction on documentary videos comprehending. 
Fig1. Means Score of ClassA

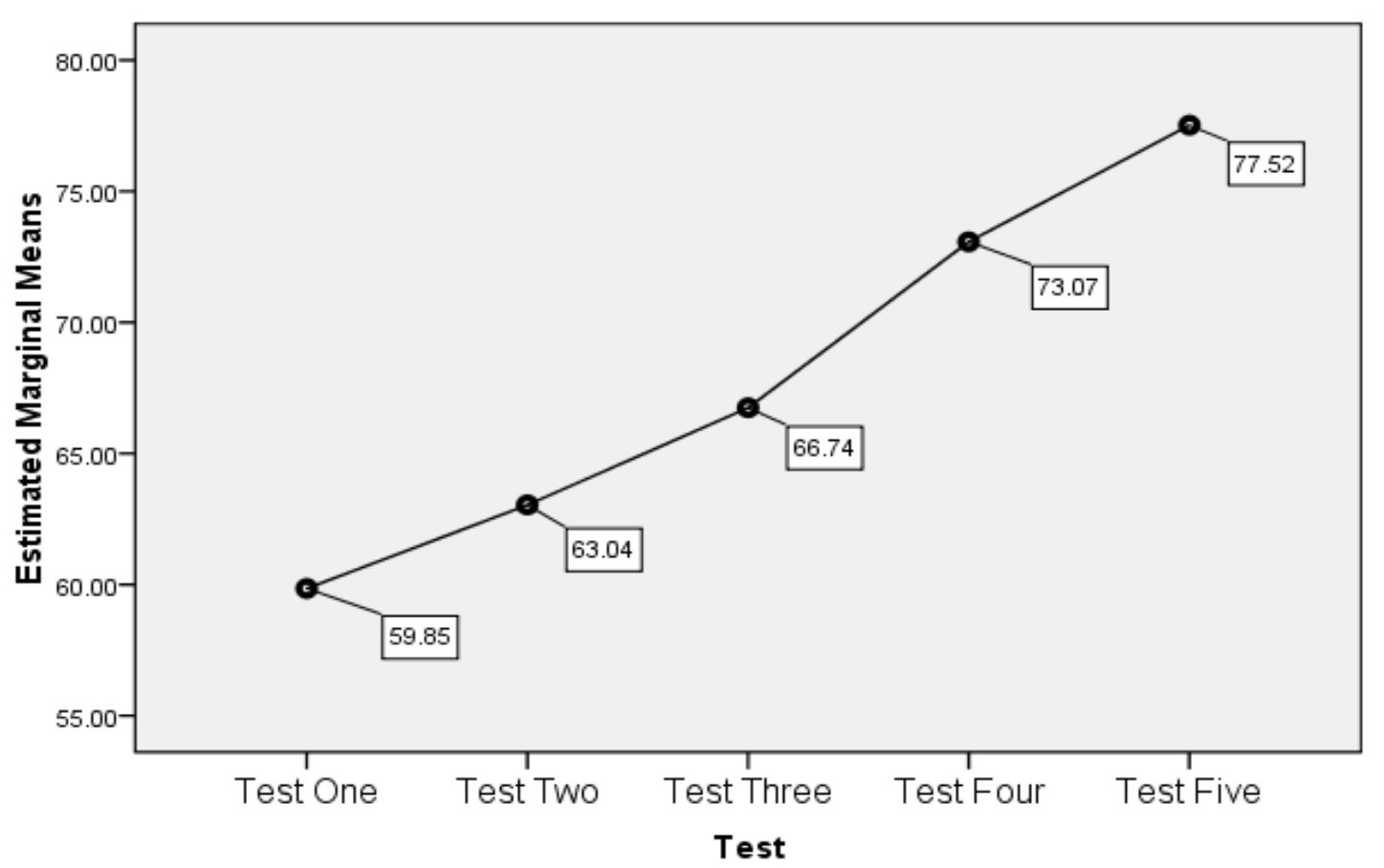

Fig. 2 is indicating the means score of class B in which the students just did the listening comprehension tasks by watching to the documentary videos.

Fig2. Means Score of Class B

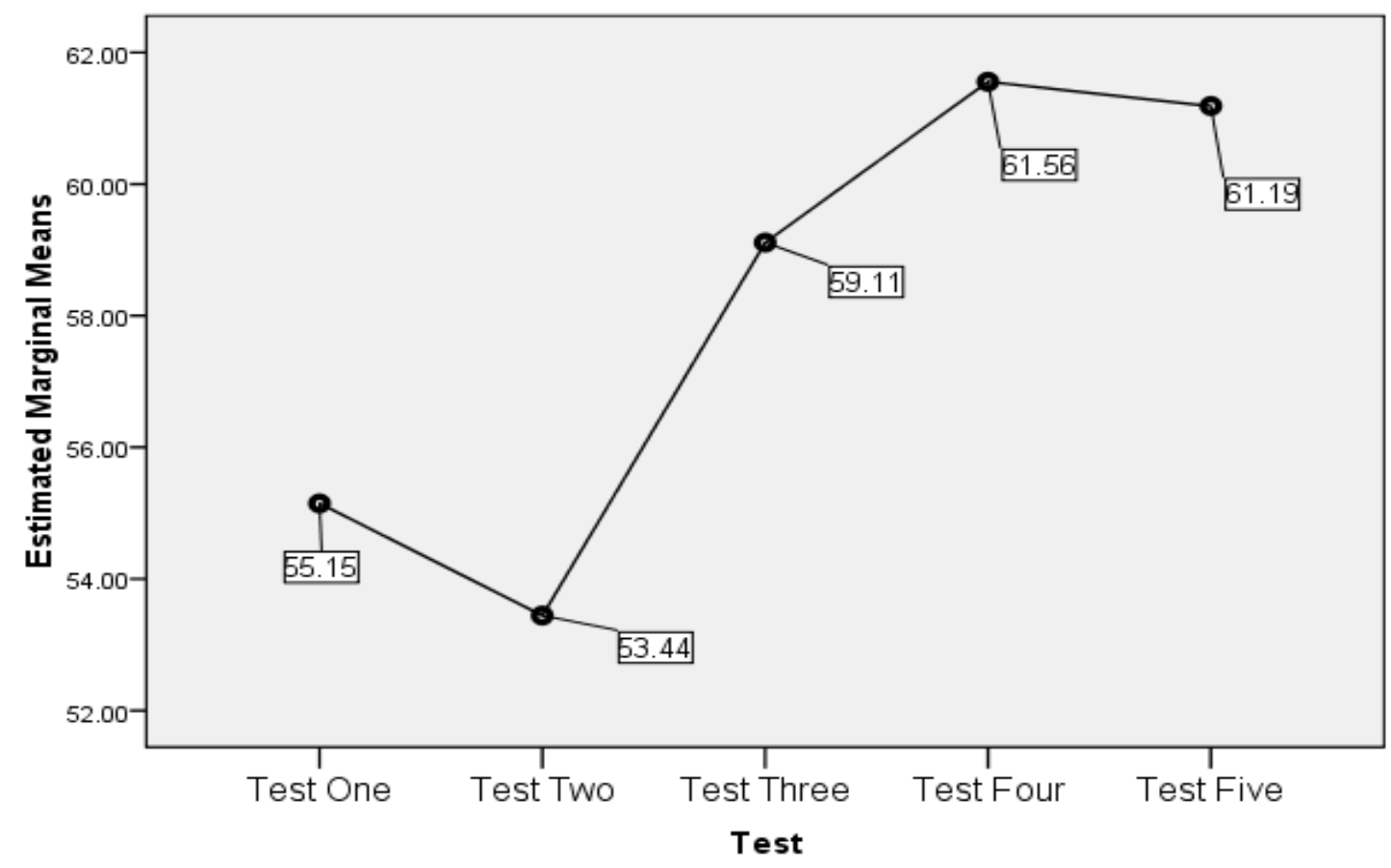


As one can see in the Fig. 2 there is some falls in the means score of this class. One can't see the stability in the means. There is 1.7 decrease between test one and test two that is quite tangible. In the final test when it is supposed that students' listening comprehension should be improved, there is also a decrease in the mean score.

\section{CONCLUSION}

The results of this investigation is a good prove for the previously done research on the effect of listening comprehension strategy instruction on improving listening comprehension in general and listening comprehension of documentary videos in specific (Macaro, 2004, 2006; Chien and Wei, 1998; Goh, 2002; Smidt and Hegelheimer, 2004).

The research question was investigating the effect of listening comprehension strategy instruction on the comprehension of documentary videos in an EFL context of advanced Iranian students. The obtained results showed that instruction of listening comprehension strategies to Iranian advanced EFL learners has a significant effect on learners listening comprehension in relation to documentary videos. The means score in the experimental group has an everlasting increasing as it was illustrated in the Fig. 1. On the other hand, the control group showed a rather unstable situation in its means score and Fig. 2 indicated this fact. The ten listening comprehension strategies that were taught in the class A are the foremost reason for the improvement of this class listening comprehension. This fact was investigated earlier by Oxford and proved.

The results of this study are devoted to the effect of listening comprehension strategy instruction on documentary video comprehension of Iranian advanced EFL students, so the implication for the future research should investigate on the following:

- Different proficiency levels of language learners

- Listening comprehension strategy instruction ESL context

- Other types of videos like News

A pedagogical implication of the findings of this study showed the importance of instructing listening comprehension strategies in order to improve their abilities to comprehend documentary videos and to improve their totality of listening comprehension. By so, teachers should work on different listening comprehension strategies in their classrooms to let their students use these factors in their language learning process.

\section{References}

[1] Anderson, J. (1980). Cognitive psychology and its implications. New York: Freeman.

[2] Bacon, S. (1992). Authentic listening in Spanish: How learners adjust their strategies to the difficulty of the input. Hispania, 75, 398-412.

[3] Bell, D. (2003). TV news in the EFL/ESL classroom: Criteria for selection. TESL$\mathrm{EJ}, 7(3)$.

Available online at http://www-writing.berkeley.edu/TESL-EJ/ej27/a2.html

(February 2009). 
[4] Botting, G. (2003). Japan's TV news in a world of its own. The Japan Times Online. Available online at http://www.japantimes.co.jp/cgi-bin/getarticle.pl5?fl20030218zg.htm (February 2009).

[5] Carrier, K. (2003). Improving high school English language learners' second language listening through strategy instruction. Bilingual Research Journal, 27(3), 383-408.

[6] Chamot, A. (2005). Language learning strategy instruction: Current issues and research. Annual Review of Applied Linguistics, 25, 112-130.

[7] Chen, Y. (2005). Barriers to acquiring listening strategies for EFL learners and their pedagogical implications. TESL-EJ, 8(4).

Available online at http://tesl-ej.org/ej32/a2.html (February 2009).

[8] Chen, Y. (2007). Learning to learn: The impact of strategy training. ELT Journal, 61(1), 20-29.

[9] Feak, C., Salehzadeh, J. (2001). Challenges and issues in developing an EAP video listening placement assessment: A view from one program. English for Specific Purposes, 20, 477-493.

[10] Field, J. (2000). Finding one's way in the fog: Listening strategies and second language learners. Modern English Teacher, 9, 29-34.

[11] Gruba, P. (2004). Understanding digitized second language videotext. Computer Assisted Language Learning, 17(1), 51-82.

[12] Gruba, P. (2006). Playing the videotext: A media literacy perspective on videomediated L2 listening. Language Learning and Technology, 10(2), 77-92.

[13] Hassan, X., Macaro, E., Mason, D., Nye, G., Smith, P., Vanderplank, R. (2005). Strategy training in language learning: A systematic review of available research. In Research evidence in education library. London: EPPI-Centre, Social Science Research Unit, Institute of Education, University of London.

[14] Hsaio, T.-Y. and Oxford, R. (2002). Comparing theories of language learning strategies: A confirmatory factor analysis. The Modern Language Journal, 86(3), 368-383.

[15] Macaro, E. (2006). Strategies for language learning and for language use: Revising the theoretical framework. The Modern Language Journal, 90(3), 320-337.

[16] Mareschal, C. (2007). Student perceptions of a self-regulatory approach to second language listening comprehension development. Unpublished doctoral dissertation, University of Ottawa, Ontario.

[17] O’Malley, J., Chamot, A. (1990). Learning strategies in second language acquisition. Cambridge: Cambridge University Press.

[18] Oxford, R., Cho, Y., Leung, S., Kim, H. (2004). Effect of the presence and difficulty of task on strategy use: An exploratory study. International Review of Applied Linguistics in Language Teaching (IRAL), 42, 1-47.

[19] Seo, K. (2000). Intervening in tertiary students' strategic listening in Japanese as a foreign language. Unpublished doctoral dissertation, Griffith University, Brisbane. 
[20] Smidt, E., Hegelheimer, V. (2004). Effects of online academic lectures on ESL listening comprehension, incidental vocabulary acquisition, and strategy use. Computer Assisted Language Learning, 17(5), 517-556.

[21] Vandergrift, L. (2007a). Recent developments in second and foreign language listening comprehension research. Language Teaching, 40, 191-210.

[22] Vandergrift, L. (2007b). Teaching students how to listen: Effects on listening achievement. Paper presented at the annual meeting of the American Association of Applied Linguistics, Cosa Mesa, CA.

[23] Wagner, M. (2006). Utilizing the video channel: An investigation of the use of video texts on tests of second language listening ability. Unpublished doctoral dissertation, Columbia University, New York.

[24] Walma van der Molen, J. (2001). Assessing text-picture correspondence in television news: The development of a new coding scheme. Journal of Broadcasting and Electronic Media, 45(3), 483-498. 